\title{
Human Resources Management For Improving Medium Small Businesses
}

\author{
Tajeri \\ Sekolah Tinggi IImu Ekonomi Muara Teweh, Indonesia \\ tajeri05555@gmail.com \\ ${ }^{*}$ Corresponding Author
}

How to Cite : Tajeri, T. (2020). Human Resources Management For Improving Medium Small Businesses. International Journal for Educational and Vocational Studies, 2 (8), 685-689. DOI: https://doi.org/10.29103/ijevs.v2i8.2760

\section{ARTICLE HISTORY}

Received: 9 June 2020

Revised: 17 July 2020

Accepted: 27 July 2020

\section{KEYWORDS}

Human Resource;

Management;

Small Businesses;

\section{ABSTRACT}

National development is an effort to improve human quality and Indonesian society conducted sustainably. Development the economy originally oriented on industrial industry growth large-scale shifts to more economic development emphasis on democratic economy. one of them through UMKM however lots of small industries that cannot develop wrong one is the rambak crackers industry in Barito Utara because of lack their UMKM ability, so many businesses that go out. With improving the quality of UMKM and the government's role is expected to be to be able to increase entrepreneur's knowledge and skills in terms of technology, facilities and infrastructure, capital and marketing.

\section{INTRODUCTION}

National development is an effort to improve the quality of Indonesian and society. It is carried out sustainably based on national capabilities. Economic development which was initially oriented towards the growth of large-scale industries shifted to economic development which was more emphasized on the people's economy (Bruch \& Hiemenz, 2019). The challenges and obstacles faced by developing countries are getting bigger regardless of the problem of the economic crisis that occurred.

Rapid of economic development is also driven by the development of information technology (An, 2016). It has led to the coordination of business operations that are more effective and efficient at increasingly low costs. The small industry is one of the backbones of the Indonesian economy and it has been proven that in difficult economic conditions small and medium industries are better able to survive, for that small and medium businesses need to be developed, one of them by increasing their capital. Small and medium businesses (UKM) are defined by the Indonesian statistical center (BPS) based on the quantity of labor. Small businesses are business entities that have a workforce of 5 to 19 people, while medium businesses are business entities that have a workforce of 20 to 99 people. The size of an industry based on the number of workers. UKM have a large market opportunity because- there is always a market for the production of their goods and services, bearing in mind that UKM are producers of goods and services, especially for people in the lower middle class with low purchasing power.

The sector that is expected to create employment opportunities in the small and medium industrial sector, because in this sector the technology used in the production process is labour-intensive technology so that with labour-intensive technology it is expected to absorb more labour. Small industries need attention because they not only provide income for most of the workforce but also are the spearhead in efforts to reduce poverty, unemployment and income distribution. However Attention is not enough; but need acute and appropriate actions (Nybo et at, . 2017).

The type of industry in each region is different, this is influenced by differences in the characteristics of the resources owned by each region. Small industries build rural economies with industries with local resources and local consumption. The case of small industries which have stopped or cannot develop properly are one of them in Barito Utara. As one of the regencies that has a strategic location and its famous natural beauty, both from foreign and domestic tourists visiting the district. This opens up opportunities to introduce both processed and processed buffalo crackers. 
Barito Utara Regency is famous for its rambak products from buffalo skin One of the prominent small industries is the cracker small industry, where this commodity is the superior commodity of Barito Utara Regency. The cracker industry is included in the agricultural products industry. Crackers are a typical regency food that has been widely marketed throughout Barito Utara Regency and several types have been marketed in various regions outside the regency. The sharp competition experienced by the crackers producer with crackers products derived from other raw materials and also the lack of human resource management that manages the crackers industry, makes this industry heavy enough to maintain business continuity.

Human resources are an important factor for every business. Quality human resources will determine the triumph or failure in a competition (Amantha, 2016). Likewise with small industries, if there are quality human resources in it will certainly make small industries triumph (Destiana, 2019). For the country's economy, the triumph of a small industry will make a country's economy better. Therefore, it is very important to improve the quality of human resources to improve performance in business. There are various aspects that need to be considered to build the quality of human resources to make small industries more prosperous. The results of the Indonesian national panel discussion on strengthening small and medium industries are formulated various factors that become obstacles in increasing the competitiveness of Indonesia's small industry performance, one of which is the low quality of human resources. The low quality includes aspects of competence, skills, work ethic, character, awareness of the importance of quality consistency and standardization of food products, as well as entrepreneurial insight. Based on the description above, the purpose of this study is to explore how to improve the management of small industry players, the role of participation and government efforts to improve human resources in the small industrial sector.

\section{LITERATURE REVIEW}

Small and medium businesses are companies that are run and independently owned. Small Business is a productive economic business that stands alone, which is carried out by individuals or business entities that are not subsidiaries or non-branch companies that are owned, controlled, or become either directly or indirectly part of medium-sized businesses or large businesses that meet the criteria. Criteria for small businesses, namely net assets of more than $\mathrm{Rp} 50,000,000$ (fifty million rupiahs) up to a maximum of $\operatorname{Rp~500,000,000~(five~hundred~million~}$ rupiahs) excluding land and buildings for business premises; or have annual sales results of more than Rp $300,000,000$ (three hundred million rupiahs) up to a maximum of $\operatorname{Rp~2,500,000,000~(two~billion~five~hundred~}$ million rupiahs).
A medium-scale business is a productive economic business that stands alone, which is carried out by an individual or business entity that is not a subsidiary or branch of a company that is owned, controlled, or becomes a part either directly or indirectly with a small business or large business by fulfilling the criteria. Criteria for medium-scale businesses, namely net assets of more than Rp 500,000,000 (five hundred million rupiahs) up to a maximum of $\operatorname{Rp} 10,000,000,000$ (ten billion rupiahs) excluding land and buildings for business premises; and has annual sales results of more than Rp2,500,000,000 (two billion five hundred million rupiahs) up to a maximum of Rp 50,000,000,000 (fifty billion rupiahs).

The Central Statistics Agency provides a definition of UKM based on the quantity of labor (Rahmana 2009). Small businesses are business entities that have a workforce of 5-19 people, while medium businesses are business entities that have a workforce of 20-99 people. Human resources are human potential which are non-material/non-financial assets(Riniwati,2016). Human resources function as an activator of an organization to realize the existence of the organization. Resources are capital that has an important position in an organization, not just organizational resources that are needed and employed because they have intellectual competence. Quality of resources relating to one's expertise, abilities and work skills (Amboningtyas, 2019). The quality of human resources refers to 1) knowledge, namely the mastery of knowledge and technology obtained through the learning process and experience 2). Skills to manipulate an object physically, 3) Ability is the attitude to do the task in entrepreneurship. also affects the quality of a human resource (Busro, 2018). To find out the quality of human resources, namely knowledge, knowledge of business management, knowledge of products or services, knowledge of consumers, promotion and marketing strategies skills namely production, communication, collaboration and organizational skills, supervision, finance, administration and accounting. 3) Capabilities, namely the ability to manage a business, make decisions, lead, control, innovate, change the situation and business environment.

\section{RESEARCH METHODS}

This research is descriptive analysis research. Descriptive analysis is a statistic that is used to analyze data by describing or describing the data that has been collected as it is without intending to make conclusions that apply to the public or generalization. Sugiyono (2004: 169). Descriptive research is a form of research aimed at describing existing phenomena, both natural phenomena and man-made phenomena. These phenomena can be in the form of activities, characteristics, changes, relationships, similarities, and differences between one phenomenon and another. 


\section{RESULTS AND DISCUSSION}

\section{Improving Resource Management of Small Industry Players}

Weak quality of human resources (HR), entrepreneurs making umkm did not dare to try innovations related to technology, making most of the small businesses grow conventionally and are a family business for generations. Entrepreneurs making crackers are difficult to adopt new technological developments to increase the competitiveness of their processed products. The limited knowledge of these rambak crackers entrepreneurs does not have the courage to try new innovations that are relatively more effective and efficient.The limitation of the quality of human resources in these rambak crackers entrepreneurs in terms of formal education as well as their knowledge and skills greatly affects the management of their business management, so that the business is difficult to develop optimally. With the global economy and the era of free trade, small industries in Indonesia are expected to be able to create markets within and outside the country and as an important source of trade balance or balance of payment surpluses. To face global competition, small industries must increase their competitive advantage, namely in terms of efficiency, productivity, mastery of technology, and high entrepreneurship which all rely on the quality of human resources.

The development of small industries needs to be spurred more quickly by increasing the quality of human resources. While various problems faced by small industries seem to have many problems rooted in human resources. Clarke (1998) mentions the ability and skills of human resources in small and medium industries will determine achievement improvement. While efforts to improve the quality of human resources are through training. Smith (1999) in his study found that training has an important meaning in economic development. Providing training directly to small industries is considered the single most effective way. However, in Indonesia the effectiveness of training is still in doubt.

Entrepreneurs who have attended government training complained that the training was often too theoretical, the time was too short, there was no follow up and often it did not suit their actual business needs (Tambunan, 2000). However, the study did not explain how to measure aspects of the training. In this study the training aspect will be measured by the amount of training received. Where the amount of training is a measure of the number of training and types of training. Work experience is an important aspect in determining the quality of human resources. As the study at the center for the study of living standards (2003), that accumulated skills at work age (energy use) one of which is rooted in the results of experience.

This is supported by hankinson, at. Al., (1997), and he stated that the aspect of experience is measured from the length of time someone has worked in the same field. Based on the Indonesian simple small industrial development plan (Menperindag, 2002) that according to the conditions of the existing problems the development activities are directed towards entrepreneurs:

1) Having the insight and entrepreneurial spirit that is tenacious, patriotic (love domestic products), and professional.

2) Able to identify, develop or take advantage of business opportunities.

3) Able to utilize productive resources and access markets (local, domestic and export).

4) Have business management skills, expertise and technical/technological skills.

5) Able to build competitiveness (with efficiency, productivity and quality, proactive-innovative approach).

All these skills, supported by the opinion of Tambunan (2000), are indispensable to maintaining or improving the performance of small industries which include improving product quality, efficiency and productivity in production, increasing sales through expanding market share and penetrating new markets.

\section{Training and achievements}

The field of training studies for small industries is not only a common problem for all small industries, but it is a legacy that assumes assumptions about training from a large field of business. The general view is that the training is a good thing that can be used to improve achievement. This has been an implicit or explicit assumption that training will improve achievement. It is difficult to try to separate the impact of training on the performance of small industries. From many studies on training and human resource development in small industries that have been carried out shows the successes and failures in obtaining training benefits. The training is expected to increase the knowledge and skills of small industry owners so that they can advance their business, among others:

\section{Able to absorb technology better}

During this time due to lack of understanding of technology makes the work of cutting skin rambak done manually using ordinary kitchen knives. Limited ability of cutting tools in cutting buffalo skin with a conventional knife. Cutting buffalo skin as a raw material for making crispy and nutritious rambak crackers is still using conventional cutting tools or knives, so that the cut results are not the same. The time used for cutting the skin as a basis for making the rambak crackers takes a long time so it is inefficient. Cutting Using a traditional knife has the disadvantage of using strong people because the skin is hard so it needs extra strength inside the deduction. The results of cutting raw material for making rambak crackers are not optimal results so the results are not the same and take a long time. 


\section{Able to improve facilities and infrastructure}

With training in human resources, information related to the progress of technological science will be better too so that the means and infrastructure which was originally very limited and also still manually / conventional. Drying buffalo and cow skin as the basic ingredients for rambak crackers These are very dependent on sunlight and the tools are all still manual, can be tricked by other methods. The improvement of facilities and infrastructure is also able to develop capital that used to be a source of personal capital, which can develop with capital from the banking sector by utilizing capital for UMKM with relatively small interest. Broadly speaking, with the increase in human resources, entrepreneurs will have the ability to manage their industry.

Micro, small and medium enterprises are one of the businesses that are currently in demand in Indonesia. Craftsmen in Indonesia have begun to grow and be creative in trying to make their UMKM known nationally and globally. This sector has a large contribution to the velocity of money in the community because of the sizeable amount of 55.2 million. UMKM from various business fields spread throughout Indonesia contributed to economic growth in the country reached 60 percent. There are ways to develop Indonesia's UMKM wings through 5p, namely product, price, place, promotion, and people as follows:

\section{Product}

In terms of products, UMKM must determine the right product to market. Products made must also be innovative, creative and interesting. To get products that are popular with the market, do a survey around to reinforce a realistic product picture. The more observant and enterprising you innovate products and services, then you will be able to develop and win business competition. You should look for products that are not yet sold in the market but are beneficial to the buyer.

\section{Price}

To determine the selling price of a product, you must carefully calculate the costs incurred during the production process. The most important costs in UMKM are capital costs and operational costs. Capital costs include institutions or financial parties that provide credit facilities for your business. While operational costs include employee salaries, raw material costs, and production costs. The selling price will be higher if both costs reach a high nominal value. A few tips for entrepreneurs who need capital costs, look for microfinance institutions that provide credit facilities with low interest, fast processing and a long period of time. The financial services authority, for example, will provide full support by asking banks to extend 20 percent of their credit to UMKM at low interest rates of 12 percent per year.

\section{Place}

The location of UMKM certainly determines market interest. By choosing a strategic and ideal location, your UMKM will quickly be recognized by the public and it is quite possible that the product will sell well. About the location, try to open UMKM in traditional markets or other locations that are crowded and densely populated. If you do not find a strategic location, consider the following things when opening UMKM, namely making sure every minute there are always vehicles passing by when opening on the side of the road, pay attention to the consumptive level of the community by looking at the number of similar businesses around the location, equipping your business with SIUP permits, HO and NPWP, etc. and most importantly adjust it to your budget.

\section{Promotion}

Some UMKM have already implemented promotions through social media and this is a good first step.

\section{People}

When you open the UMKM, make sure the human resources involved in your business are people who understand the business. You do not hesitate to make the process of recruiting employees properly. Both of the scale and type of your business. Although your business is still micro-scale, the employee selection process must follow a recruitment process that is modern and tested, not just relying on references from acquaintances or relatives. It is better in selecting employees, you must prioritize the character of HR business-oriented, can and dare to take measured business risks, have and understand business financial statements and be able to create and run cost-effective posts.

\section{The role of government in increasing resources}

The presence of a strong UKM can be a motivator for other entrepreneurs. UKM performance can be improved if various obstacles as mentioned above can be loosened in capital and other technology. For UKM, the skill of the owner or manager of a business is a determining factor. Therefore, the HR development approach becomes very strategic. Through improving the quality of HR skills, it is expected that various obstacles faced by UKM can be overcome. Quality improvement and human resource development are carried out simultaneously with the creation of a conducive climate for UKM to grow and develop.

The conducive climate as stated in advance is designed in a macro that is public and generally accepted. This needs to be done considering the number of UKM very large. In addition to the above, the government also takes three approaches that can be taken by the government in fostering small industries, i.e.:

\section{Non Policy approach}

It is focused on industries that are engaged in lower spectrum (marginal activities). This type of approach was 
chosen given that government intervention in general would create relatively high bureaucratic costs.

\section{Protection approach}

Protection policies generally form a prohibition for large-scale industries to produce certain goods, import restrictions on substitute products, control over the spread of technological innovations that can cause sudden shocks to small industries. This policy tends to benefit producers rather than consumers.

\section{Stimulaltion approach}

This type of policy focuses more on the supply side in the form of granting credit, providing raw materials and production equipment, and administering courses. This type of policy has a negative impact, among others in the form of displacement of business units that are not or have not been served by the program. Improving the quality of human resources is done through improving management and entrepreneurial skills. This concerns two aspects of HR which are generally more effective through a learning by doing approach. For UKM entrepreneurs it is easier to learn through direct practice than learning complicated theories, especially concerning entrepreneurship.

This experience shows that entrepreneurship in most cases grows from entrepreneurial families as well. Such an approach will tend to continue to be developed. Various apprenticeship programs, incubators, business clinics, field consultations are now being drafted through various pilot projects which can later be replicated elsewhere. Thus, the HR development approach will be prioritized in efforts to popularize and cultivate entrepreneurship, especially in the context of fostering UKM.

It is important to realize that this kind of approach is not quick to see (quick yielding), but is a long-term investment in which the fruits may be enjoyed after some time. However, each long-term investment usually also has a relatively long life cycle. Once successful in building a generation of young entrepreneurs who are tough and reliable, then the same thing will experience replication for subsequent generations.

This kind of process will continue to occur repeatedly so that the development wheel rotates by itself. Thus, one day each region will have a strong and independent regional entrepreneur. Therefore, it is expected that UKM entrepreneurs must proactively think about this and engage directly as entrepreneurs in order to strengthen the economy of each region.

\section{CONCLUSION}

Weak Quality of Human Resources (HR), Entrepreneurs making community activity unit do not dare to try innovations related to technology, thus making the majority of small businesses grow conventionally and are family businesses that are hereditary. By improving the quality of human resources, community activity unit will be able to develop Indonesian community activity unit wings of products, prices, places, promotions, and people. The role of government in improving the quality of human resources is done through improving management and entrepreneurial skills.

This concerns two aspects of HR that are generally more effectively carried out through a learning by doing approach that must be maintained. For community activity unit entrepreneurs, it is easier to learn through direct practice than learning complicated theories, especially concerning entrepreneurship.

\section{REFERENCES}

Amantha, G. K. (2016). Analisis Budaya Kerja dalam Menciptakan Sumber Daya Manusia yang Berkualitas (Studi pada Biro Organisasi Sekretariat Daerah Provinsi Lampung) (Doctoral dissertation, Fakultas Ilmu Sosial Dan Ilmu Politik)

Amboningtyas, D. (2019). Pengembangan Capacity Building Dalam Peningkatan Kualitas Sumber Daya Manusia Pada Usaha Kecil Menengah Di Kecamatantugu, Semarang. Jurnal Pendidikan Ekonomi, 3(2).

An, M. (2016, April). Reflections on the Driven Mechanism of Network Economy on ComputingTechnology (ICEMCT-16). Atlantis Press.

Bruch, M., \& Hiemenz, U. (2019). Small-and medium-scale industries in the ASEAN countries: agents or victims of economic development?. Routledge.

Busro, M. (2018). Teori-teori manajemen sumber daya manusia. Prenada Media.

Destiana, D. (2019, February). Pengaruh Teknologi Informasi Berbasis Android (Smartphone) Dalam Pendidikan Industry 4.0. In Prosiding Seminar Nasional Program Pascasarjana Universitas Pgri Palembang (Vol. 12, No. 01).

Nybo, L., Kjellstrom, T., Bogataj, L. K., \& Flouris, A. D. (2017). Global heating: Attention is not enough; we need acute and appropriate actions.

Riniwati, H. (2016). Manajemen Sumberdaya Manusia: Aktivitas Utama dan Pengembangan SDM. Universitas Brawijaya Press. 